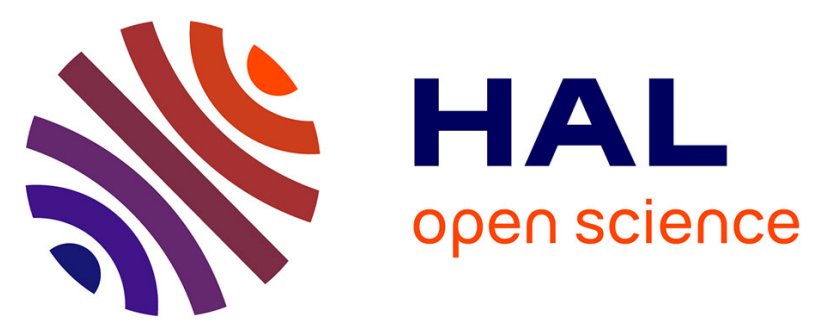

\title{
Responses of a Northern Adriatic community to seasonality and short-term hydrological changes in the Po river
}

\author{
Gloria Massamba N’Siala, Valentina Grandi, Mirko Iotti, Giuseppe \\ Montanari, Daniela Prevedelli, Roberto Simonini
}

\section{To cite this version:}

Gloria Massamba N'Siala, Valentina Grandi, Mirko Iotti, Giuseppe Montanari, Daniela Prevedelli, et al.. Responses of a Northern Adriatic community to seasonality and short-term hydrological changes in the Po river. Marine Environmental Research, 2008, 66 (4), pp.466. 10.1016/j.marenvres.2008.08.002 . hal-00501978

\section{HAL Id: hal-00501978 \\ https://hal.science/hal-00501978}

Submitted on 13 Jul 2010

HAL is a multi-disciplinary open access archive for the deposit and dissemination of scientific research documents, whether they are published or not. The documents may come from teaching and research institutions in France or abroad, or from public or private research centers.
L'archive ouverte pluridisciplinaire HAL, est destinée au dépôt et à la diffusion de documents scientifiques de niveau recherche, publiés ou non, émanant des établissements d'enseignement et de recherche français ou étrangers, des laboratoires publics ou privés. 


\section{Accepted Manuscript}

Responses of a Northern Adriatic Ampelisca-Corbula community to seasonality and short-term hydrological changes in the Po river

Gloria Massamba N'Siala, Valentina Grandi, Mirko Iotti, Giuseppe Montanari, Daniela Prevedelli, Roberto Simonini

PII: $\quad$ S0141-1136(08)00197-9

DOI: $\quad$ 10.1016/j.marenvres.2008.08.002

Reference: $\quad$ MERE 3279

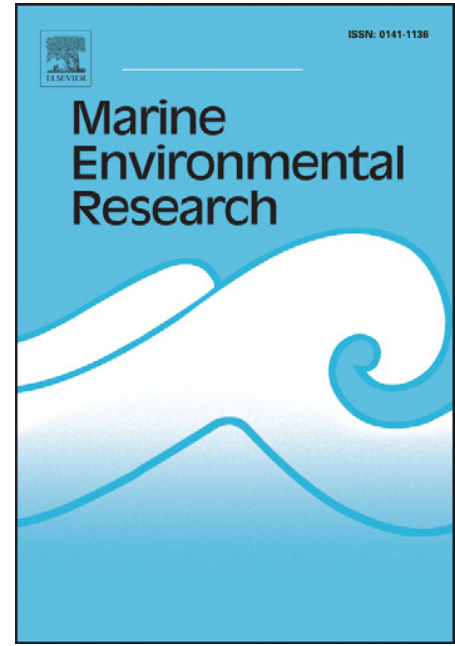

To appear in: $\quad$ Marine Environmental Research

Received Date: $\quad 19$ March 2008

Revised Date: $\quad 4$ August 2008

Accepted Date: 6 August 2008

Please cite this article as: N'Siala, G.M., Grandi, V., Iotti, M., Montanari, G., Prevedelli, D., Simonini, R., Responses of a Northern Adriatic Ampelisca-Corbula community to seasonality and short-term hydrological changes in the Po river, Marine Environmental Research (2008), doi: 10.1016/j.marenvres.2008.08.002

This is a PDF file of an unedited manuscript that has been accepted for publication. As a service to our customers we are providing this early version of the manuscript. The manuscript will undergo copyediting, typesetting, and review of the resulting proof before it is published in its final form. Please note that during the production process errors may be discovered which could affect the content, and all legal disclaimers that apply to the journal pertain. 
1 Responses of a Northern Adriatic Ampelisca-Corbula community to seasonality and short-term hydrological changes in the Po river

3

4 Gloria Massamba N'Siala ${ }^{\text {a }}$, Valentina Grandi a , Mirko Iotti ${ }^{\text {a }, ~, ~ G i u s e p p e ~ M o n t a n a r i ~}{ }^{\text {b }}$,

5 Daniela Prevedelli ${ }^{\text {a }}$, Roberto Simonini ${ }^{\text {a, }}$

${ }^{a}$ Dipartimento di Biologia Animale, Università degli Studi di Modena e Reggio Emilia 8 via Campi 213/D, 41100 Modena, Italy

9 b ARPA Emilia-Romagna, Struttura Oceanografica Daphne, via Vespucci, Cesenatico 10 (FC), Italy

* Corresponding author. Tel. ++3959-2055562, Fax ++3959-2055548, e-mail: roberto.simonini@unimore.it

\section{Abstract}

During the $20^{\text {th }}$ century, increased nutrient inflow has increased the frequency and intensity of eutrophication events in the North-western Adriatic Sea. More recently, evidence of a reduction in the Po river flow and a recovery of the benthic environment were reported. We examined the role played by Po river regime and seasonality in determining the temporal pattern of macrozoobenthos variation: samples were collected from a site located 10-12 km off Cesenatico during two years from October 2004 to September 2006, when the mean Po discharge remained exceptionally low. 88 taxa were found, and the community was dominated by few species: Ampelisca diadema, Lumbrineris latreillii, Corbula gibba Aricidea claudiae, Levinsenia gracilis and Nucula nucleus account for about $80 \%$ of total abundances. The density of these species exhibited a marked seasonal variability. Moreover, the total abundance and the density of the sensitive species, A. diadema, were negatively affected by several disturbance events (hypoxic conditions, frequent storms and an anomalous winter flood) that occurred between November 2005 and March 2006. The reduction of C. gibba and the increase of A. diadema densities observed in the investigated period, and verified recently by other authors, could be related to the reduction in river inputs as a consequence of climatic changes. 


\section{Keywords}

2 macrozoobenthos; temporal scale; river regime; seasonality; Northern Adriatic Sea

\section{1. Introduction}

5 The Northern Adriatic Sea is a semi-enclosed and very shallow marine region. Along

6 the North-western side, particularly near the Emilia-Romagna coastline, the terrigenous

7 inputs of the Po and other rivers and the counter-clockwise circulation of the Adriatic

8 Sea favour the occurrence of significant seasonal haline stratification and a high trophic

9 state (Russo et al., 2002, 2005; Montanari and Pinardi, 2006). Eutrophication of the

10 northern Adriatic Sea, marked by acute events such as red tides, extensive mucus

11 aggregates, anoxic bottom conditions and mass mortalities of benthic animals has been

12 known for centuries (Crema et al., 1991 and reference therein). Yet, after World War II,

13 the Northern Adriatic Sea has been subjected to an increased nutrient inflow from the

14 Po and other rivers, which would have enhanced primary production near the surface

15 and oxygen demand near the bottom. As a consequence, the periodicity and extent of

16 these eutrophication events increased, becoming almost annual between 1970s and

17 1990s (Justic, 1987; Crema et al., 1991; Vollenweider et al., 1992; Bucci et al., 1992;

18 Marchetti and Verna, 1992; Justic et al., 1995). These events badly affected not only

19 tourism and fisheries, but also caused a dramatic change in the macrozoobenthic

20 communities, which are widely-used ecological indicators of the "health" of marine and

21 estuarine ecosystems (e.g. Borja and Dauer, 2008). Comparisons between data from

22 collections carried out off the coast of Ravenna in 1934-1936 (Vatova, 1949) and in

23 1989, revealed that the "historical" fine-grain sand (Sables fins bien calibres, SFBC,

24 Pérès and Picard [1964]) and coastal-terrigenous mud (Vases terrigènes côtières, VTC,

25 Pérès and Picard [1964]) biocenoses had been replaced by assemblages characterized by

26 an abundance of dominant, opportunistic species, such as the bivalve Corbula gibba,

27 that are indicators of sediment instability, organic enrichment and anoxic conditions,

28 (Crema, 1991; Cavallini et al., 2005). During the 1990s, it was demonstrated that this

29 change in the structure and composition of the macrozoobenthos was general feature

30 over the whole western coastal area of the Northern Adriatic Sea (Simonini et al., 2004).

31 However, the high biomass, species richness and diversity observed at most sites

32 suggest the occurrence of less extreme conditions, compared with other highly- 
1 eutrophicated coastal areas, such as the Baltic Sea, the Gulf of Mexico and the Black

2 Sea (Moodley et al., 1998; Simonini et al., 2004). More recently, it appeared that the 3 communities were evolving towards a higher degree of structural complexity: the 4 establishment of dense populations of the fossorial amphipod Ampelisca diadema, 5 which is considered as a bioindicator of environmental recovery, and an increase in 6 diversity and evenness indices were reported (Occhipinti Ambrogi et al., 2005). The 7 considerable temporal variability in composition and density of the community of sandy 8 and muddy bottoms of the Northern Adriatic was attributed to the additive effect of 1) 9 inter-annual variation of the hydrographical regime of the Po river and coastal waters 10 (Occhipinti Ambrogi et al., 2005; Simonini et al., 2005b) and 2) high seasonal variation 11 in temperature and photoperiod (Simonini et al., 2004, 2005a, 2007). These factors can 12 modulate biological events, playing an important role in determining the community 13 structure and composition. In general, in temperate coastal areas, the abundance and/or 14 diversity of benthic communities declines over the autumn and winter period, and 15 recovers in summer, when the reproduction, recruitment and settlement of most species 16 occurs (Dauvin, 1988; Rosenberg et al., 1992; Salen-Picard et al, 2003; Simonini et al., 17 2005a,b). The seasonal variations in sedimentation rates and freshwater and terrigenous 18 organic inputs caused by floods and droughts can also affect the population dynamics of 19 the different species, with major consequences at the community level (Largier, 1993; 20 Grémare et al., 1998; Salen-Picard et al., 2002, 2003; Occhipinti Ambrogi, 2005; 21 Labrune et al., 2007).

22 These issues have become particularly relevant in recent years when, within a large 23 scale climatic change scenario, an increase in sea water temperature and a drastic 24 reduction in the Po river loads were observed (Russo et al, 2002, 2005; Montanari et al., $252005,2006,2007)$.

26 In this paper we investigated the variation in structure and composition of 27 macrozoobenthic communities sampled from October 2004 to September 2006 in the 28 coastal area of Emilia-Romagna, Italy (Fig. 1). The data were integrated with 29 information on 1) the Po and Northern Adriatic hydrographical regime, and 2) some 30 chemical and physical variables of the water column and sediment properties. The aim 31 was to identify the role played by environmental seasonal changes and the Po river 32 regime in determining the short and medium-term pattern of macrozoobenthos 
1 variation, taking into account the community characteristics that had previously been

2 described for the same area.

3

4 2. Materials and methods

52.1 Study area and hydrological regime of the Po river during the study period

6 The sampling activities were performed from October 2004 to September 2006 in the

7 CEBEB (Cesenatico-Bellaria Bianco) area, which is a square $1 \times 1 \mathrm{~km}$ sector used as a

8 reference site in a previous investigation on the effects of dumping of dredged harbour

9 sediments on benthic assemblages (Simonini et al., 2005b, Fig. 1). The CEBEB is

10 located 10-12 km off the Cesenatico harbour at a depth of 11-13 m. The sea bottom is

11 composed of infralittoral muds, with a high percentage of silt. The biocenoses living in

12 these bottoms are characterized by high densities of surface-deposit feeder species, such

13 as the ampeliscid amphipod Ampelisca diadema, the corbulid bivalve Corbula gibba,

14 the lumbrinerid polychaete Lumbrineris latreillii and some small-sized spionid and

15 paraonid polychaetes (Simonini et al., 2005b). It represented an ideal site to investigate

16 the natural pattern of temporal variation of benthic communities because of the distance

17 from the coast and from direct source of human disturbance (e.g. aquaculture, drilling

18 platforms, dumping/dredging areas). Moreover, it is representative of the benthic

19 ecosystems of the whole area between the Po river mouth and the promontory of

20 Gabicce at a depth of 8-30 m (Simonini et al, 2005b). This area is strongly influenced

21 by seasonal variation in the main current regime and river runoff (Simonini et al., 2004,

22 2005b; Occhipinti Ambrogi et al., 2005; Russo et al., 2005). The Po regime is highly

23 seasonal, with its maximum flow in spring and autumn and minimum in summer and

24 winter. During the period 1917-2006, the mean Po flow at Pontelagoscuro (4455'16"

$25 \mathrm{~N}, 11^{\circ} 36^{\prime} 29^{\prime}$ E) was about $1472 \mathrm{~m}^{3} \mathrm{~s}^{-1}$, with a peak of $9650 \mathrm{~m}^{3} \mathrm{~s}^{-1}$ in October 2000.

26 During the study period, the mean annual discharge of the Po river remained low $\left(1^{\text {st }}\right.$

27 year, October 2004-September 2005: $891 \mathrm{~m}^{3} \mathrm{~s}^{-1} ; 2^{\text {nd }}$ year: October 2005-September

28 2006: $756 \mathrm{~m}^{3} \mathrm{~s}^{-1}$ ) with exceptional minima of only $300-350 \mathrm{~m}^{3} \mathrm{~s}^{-1}$ during the summers

292005 and 2006. The most important flow event was registered just after the beginning of

30 the investigation (November 2004, $\max .4600 \mathrm{~m}^{3} \mathrm{~s}^{-1}$ ), and no other significant events

31 were registered during the first year. During the second year, three minor discharge

32 peaks were observed in autumn (October, November and December 2005, max. 2800 
$1 \mathrm{~m}^{3} \mathrm{~s}^{-1}$ ) and there was an anomalous high flow event in winter 2006 (February-March

2 2006, $2400 \mathrm{~m}^{3} \mathrm{~s}^{-1}$ ) (Fig. 1). The peaks in Po river flow often induce a severe reduction

3 in the superficial water salinity, which can fall to less than $30 \mathrm{psu}$, and can cause water

4 stratification phenomena. The effect of fresh-water inputs decreases with water depth

5 and, at bottom level, the salinity ranged between 33-38 psu (Montanari and Pinardi,

6 2006).

7 The storms driven by the NE and SE winds (Bora and Scirocco), that frequently occur

8 in the Northern Adriatic Sea from December to late March, could cause a significant

9 stress to the benthic ecosystem due to sediment re-suspension and sedimentation

10 phenomenon (Matteucci and Frascari, 1997; Simonini et al., 2007). The storm intensity,

11 estimated using the wave-height recorded at the AGIP (Azienda Generale Italiana

12 Petroli) "GaribaldiC/Cervia B" oil rig (2 km SE to CEBEB), was at a maximum

13 between late autumn and early spring. In fact, between November 2004 and April 2005,

14 three severe storms (waves more than $3 \mathrm{~m}$ high) were registered. During the December

15 2005-March 2006 period, five storm events were recorded (Fig. 1). The data on the Po

16 river flow and wave height were obtained from the annual report on the eutrophication

17 of the Emilia-Romagna coastal waters (Montanari et al., 2005, 2006, 2007;

18 http://www.arpa.emr.it/Daphne/).

\subsection{Sampling plan and data acquisition}

21 Taking into account the high heterogeneity of the main biotic and abiotic variables, not only at inter- but also at intra-seasonal level (Montanari and Pinardi, 2006), in order to obtain an homogeneous (but not regular) distribution of sampling dates within seasons and ensure the representativeness of samples, we adopted a two-stage sampling strategy. For each month (of each season) the date of sampling was randomly chosen and the time between two consecutive samplings ranged from 2 to 6 weeks. Because sampling times are not spaced at equal intervals, the inadequate estimation of the intra-season temporal variation should not be a problem (Morrisey et al, 1992; Underwood, 1996). Twenty-four sampling surveys were carried out using the oceanographic M/S “Daphne

30 II' of ARPA (Regional Agency for Prevention and the Environment of Emilia31 Romagna). The sampling for macrozoobenthos and sediment was carried out using a 32 Box-Corer with a surface of $200 \mathrm{~cm}^{2}$. Seven replicates were collected at each month: six 
1 were used for the macrozoobenthos, one for granulometric analysis and Total Organic

2 Carbon (\%TOC). Each replicate was subdivided in two layers: superficial $(0-5 \mathrm{~cm}$ 3 depth) and deep (> $5 \mathrm{~cm}$ depth): only the superficial layer was considered because 4 previous investigation had highlighted that the $90-95 \%$ of organism, in terms of 5 abundance and biomass, occurred in the upper $5 \mathrm{~cm}$ of sediment (Simonini et al., 2004, 6 2005b). The samples for macrozoobenthos analysis were processed through sieves with 7 mesh size of $0.5 \mathrm{~mm}$ and the retained material was preserved in $4 \% \mathrm{CaCO}_{3}$ buffered 8 formalin in seawater. The near-bottom chemical and physical data (temperature, 9 salinity, $\mathrm{pH}$, conductibility, dissolved oxygen, $C h l a$ ) were measured using a Hydronaut, 10 model Ocean Seven316 CTD. Water transparency was obtained using the Secchi disk 11 method (Montanari and Pinardi, 2006). The granulometric and \% TOC analyses were 12 performed in accordance with the ICRAM (Istituto Centrale per la Ricerca scientifica e 13 tecnologica Applicata al Mare) guidelines 14 (http://www.icram.org/Acrobat/Libro/Metodologie_analitiche/metodologie_analitiche.h

$15 \mathrm{tm})$. The residual material obtained from the sample sieving was sorted in the 16 laboratory, by separating the organisms according to phylum. The macrofauna was 17 preserved in $70 \%$ ethylic alcohol. As a rule, the organisms were identified to species 18 level: in a few cases the identification was limited to genus or family. The data from each sampling month were obtained by the sum of their respective replicates.

\subsection{Data analysis}

22 The degree of differentiation of benthic communities on year and seasonal scales was assessed using a two factors nested design. We considered two factors: Year (two levels: first $\left[1^{\text {st }}\right]$ and second $\left[2^{\text {nd }}\right]$ ); Season (nested in Year, with four levels: Autumn $\left[\mathrm{Au} 1^{\text {st }}, \mathrm{Au} 2^{\text {nd }}\right]$, Winter [Wi $1^{\text {st }}$, Wi $2^{\text {nd }}$, Spring [Sp $1^{\text {st }}$, Sp $\left.2^{\text {nd }}\right]$, Summer $\left[\mathrm{Su} 1^{\text {st }}, \mathrm{Su}\right.$ $\left.\left.2^{\text {nd }}\right]\right)$. The three samplings performed in each season were considered as replicates (Date). This approach was chosen over an orthogonal Year x Season design because preliminary analyses performed according with the orthogonal design highlighted significant Season and/or Year effects, but no significant interaction between the two factors for any of the investigated variables, suggesting that the season effect was the same in the two years (data not shown). Moreover, the nested design allowed the direct comparison of the magnitude of variation on the two temporal scales (Morrisey et al, 
1 1992). The critical values of the $F$ tests performed according with the nested design

2 were: $F_{\text {crit } 1,6, \alpha<0.05}=5.99$ for the factor Year; $F_{\text {crit } 6,16, \alpha<0.05}=2.74$ for the factor Season.

3 Multivariate analyses were performed with $2^{\text {nd }}$-root transformed abundance data.

4 Outputs from non-metric multidimensional scaling (n-MDS) ordination models of the

5 Bray-Curtis similarity matrix were obtained. The differentiation of communities on

6 inter-annual and season scale was tested using a two-way nested ANOSIM (analysis of

7 similarity) randomisation-permutation test. One-way ANOSIM was also performed to

8 compare the communities from different seasons a posteriori. The $\%$ similarity or

9 dissimilarity within/between groups (years or season within years), and the species

10 making the greatest contribution to dissimilarity among years or seasons, were

11 investigated using the similarity percentage breakdown procedure (SIMPER). The

12 relationships between multivariate community structure and environmental variables

13 were examined using the BIOENV procedure. The BIOENV compares the (rank)

14 similarity matrices from biotic and abiotic variables and chooses that subset of

15 environmental variables which provides a good match between them, which is

16 expressed in term of a matching coefficient (the Spearman coefficient, $\rho_{\mathrm{s}}$ ) (Clarke and

17 Ainsworth, 1993). The multivariate analyses were carried out using PRIMER V6

18 software (Clarke and Warwick, 2001).

19 The two-way nested ANOVA was performed to analyze the inter-annual and seasonal

20 differentiation of several univariate measures: the mean Po river flow observed during

21 the four weeks before the sampling, the chemical and physical variables of the bottom

22 water (temperature, dissolved oxygen, transparency, Chl a), \%(silt+clay) and \% TOC of

23 the sediment, the main ecological indices (number of taxa, abundance, Shannon-Wiener

24 diversity [Log e]), the density of the three dominant species (Ampelisca diadema,

25 Corbula gibba and Lumbrineris latreillii) and three very common species (Aricidea

26 claudiae, Levinsenia gracilis and Nucula nucleus). The homogeneity of variances was

27 verified a priori using the Cochran C-test, transforming the values (log- or angular-

28 transformation) when necessary.

29 The Spearman rank correlation test $\left(n=24, r_{s}\right.$ crit $\left.=0.41\right)$ was used to investigate

30 relationships between the diversity indices, the density of A. diadema, C. gibba, L.

31 latreillii, A. claudiae, L. gracilis, N. nucleus and the environmental variables. 
1 The multivariate analyses were carried out using PRIMER V6 software (Clarke and

2 Warwick, 2001).The univariate analyses were performed by means of $\mathrm{R}$ (http://www.r-

3 project.org/) and Microsoft Excel software.

\section{3. Results}

\section{$6 \quad 3.1$. Environmental variables}

7 Most of the seawater chemical-physical variables and the Po river discharge (ANOVA,

8 log transformation: Year, $\mathrm{F}=0.36, \mathrm{p}>0.56$; Season, $\mathrm{F}=3.4, \mathrm{p}<0.05)$ exhibited significant

9 seasonal and low inter-annual variability (Fig. 1, 2).

10 The sea-bottom temperature showed marked cyclical variation during the year: 11 significant differences were observed only at season level (ANOVA, log 12 transformation: Year, $\mathrm{F}<0.01, \mathrm{p}>0.95$; Season, $\mathrm{F}=16.4, \mathrm{p}<0.001$, Fig. 2). The highest 13 temperatures were observed in summer (July 05-August 05: $24{ }^{\circ} \mathrm{C}$; August 2006, $1423.8^{\circ} \mathrm{C}$ ); the lowest in winter (January 05-February 05: $6.5^{\circ} \mathrm{C}$; February 06: $6.5^{\circ} \mathrm{C}$ ). 15 Anomalous high-water temperature $\left(19.0^{\circ} \mathrm{C}\right)$ was observed in November 2005.

16 Bottom water concentrations of dissolved oxygen and \% saturation were closely related $17\left(r_{s}=0.91\right)$ : they exhibited significant seasonal variation with the same pattern in the two 18 years (ANOVA on $\left[\mathrm{O}_{2}\right], \log$ transformation: Year, $\mathrm{F}<0.01, \mathrm{p}>0.95$; Season, $\mathrm{F}=2.9$, $19 \mathrm{p}<0.05$, Fig. 2). The dissolved oxygen was inversely correlated with temperature $20\left(\mathrm{r}_{\mathrm{s}}=0.87\right)$ : in fact, the highest oxygen concentrations (about $10 \mathrm{mg}^{-1}$ ) were observed in winter, the lowest at the end of summer or at the begin of autumn. In particular, shortterm hypoxic conditions were observed in the autumn of the $2^{\text {nd }}$ year (November 2005), in correspondence with the occurrence of the anomalous high-water temperature.

24 The $\mathrm{pH}$ was correlated with dissolved oxygen $\left(\mathrm{r}_{\mathrm{s}}=0.61\right)$, but did not vary significantly at annual and seasonal level (ANOVA, untransformed data: Year, $\mathrm{F}=0.04, \mathrm{p}>0.83$; Season, $\mathrm{F}=1.15$, $\mathrm{p}>0.37$, Fig. 2). Most of the time, $\mathrm{pH}$ ranged from 8 to 8.25 , with the exception of November 2005, when, in correspondence with the minimum of dissolved oxygen, the $\mathrm{pH}$ was 7.85 .

The concentrations of $C h l a$, considered as an estimate of the phytoplankton biomass, varied seasonally but not between the two years (ANOVA, log transformation: Year,

$31 \mathrm{~F}=0.89, \mathrm{p}>0.38$; Season, $\mathrm{F}=2.9, \mathrm{p}<0.05$, Fig. 2). Chl $a$ concentrations $>10 \mu \mathrm{g} \mathrm{l}^{-1}$, which 
1 indicated eutrophic conditions, were observed during the winter months: in February 2 2006, a maximum value of $32 \mu \mathrm{g}^{-1}$ Chl $a$ was measured.

3 The bottom salinity did not exhibit significant inter-annual or seasonal variation

4 (ANOVA, log transformation: Year, $F=0.31, p>0.59$; Season, $F=1.7, p>0.18$, Fig. 2). It

5 ranged between 36 and 38 psu, with minima of 35 and 34.5 psu in November 2004 and

6 December 2005, in correspondence with the two peaks of the Po river flow.

7 Nevertheless, the correlation with the Po river flow was rather low $\left(r_{s}=-0.34\right)$, probably

8 because of the low discharge observed during the investigated period.

9 The water-transparency also varied at seasonal level (ANOVA, log transformation:

10 Year, $\mathrm{F}=0.3$, p $>0.60$; Season, $\mathrm{F}=4.3$, $\mathrm{p}<0.01$, Fig. 2). During summer, when the meteo-

11 marine conditions are more stable, the Secchi-dish was visible at a depth of up to 8-9 $\mathrm{m}$.

12 Transparency started declining with the first storm events at the end of summer. Lower

13 transparencies were observed during the second year winter (January-March 2006),

14 when values of less than two meters were measured, because of the high concentration

15 of suspended organic and inorganic particles in the water column due to storms and Po

16 river discharge.

17 The sediment composition was dominated by mud and silt (75 to $94 \%$ ) throughout the

18 investigation (ANOVA on \% mud-silt, angular transformation: Year, $\mathrm{F}=2.3, \mathrm{p}>0.17$;

19 Season, $\mathrm{F}=1.1, \mathrm{p}>0.4$, Fig. 2). The \% TOC showed significant seasonal variation: the

20 highest values (1.5-2\%) were observed at the end of winter and the begin of spring

21 (ANOVA, angular transformation: Year, F=1.2, p>0.31; Season, F=3.2, p<0.05, Fig. 2).

22 The period November 2005-March 2006, has been highlighted in grey in the plots of 23 environmental (Fig. 2) and biotic variables (Fig. 4) because this featured several 24 disturbance events (frequent storms, an anomalous winter flood and, overall, hypoxic 25 events associated with the anomalous high temperatures of November 2005)

\subsection{Macrozoobenthos}

28 Throughout the course of the investigation 10988 individuals, belonging to 88 taxa, 29 distributed among 9 phyla were found (in order of abundance: arthropods, annelids, 30 molluscs, nemertines, echinoderms, sipunculids, phoronids, cnidarians, echiurians, 31 ascidians). The polychaete annelids were the most important group in term of taxa (47 32 taxa, $53 \%$ of the total), followed by the molluscs ( 25 species, mainly bivalves) and the 
1 arthropods (7 taxa). Yet, arthropods were the most important group in term of

2 abundance with 5465 individuals; most of them (97\%) being the amphipod Ampelisca

3 diadema. The remaining 6 phyla were represented by 9 taxa and contributed marginally

4 to the overall abundances.

5 The multivariate analyses performed on $2^{\text {nd }}$-root transformed data highlighted that the

6 macrozoobenthic communities varied among season, but most of the variability was

7 observed between years (ANOSIM; Years: R=0.62, $\mathrm{p}<0.05$; Season (Y) $\mathrm{R}=0.51$,

$8 \mathrm{p}<0.01)$. The Bray-Curtis dissimilarity between the two years was $48 \%$, while the

9 dissimilarity between seasons ranged from 31 to $38 \%$ in the first year and from 38 to

$1055 \%$ during the second year (SIMPER, Table 1). The MDS ordination plot relating to

11 each sampling date showed 1) two main groups corresponding to the first and the

12 second year, respectively, 2) several sub-groups corresponding to the year-season

13 period of sampling: in particular the point referring to the $2^{\text {nd }}$ year winter, characterized

14 by several disturbance events, segregated apart from the others (Fig. 3).

15 The BIOENV analysis, that relates macrobenthos structural changes to the variability of

16 environmental parameters, highlighted that the correlation between the environmental

17 and biological similarity matrix was rather low. The transparency (related to storm

18 events and Po river flow), temperature (correlated with dissolved oxygen) and mean Po

19 river flow were the combination of variables that gave the highest rank correlation

$20\left(\rho=0.421,2^{\text {nd }}\right.$ root transformed abundances $)$.

21 The SIMPER analysis highlighted that the community was characterized by the

22 presence of a few dominant species typical of off-shore muddy bottoms. Only 12

23 species contributed at least $3 \%$ to the total abundances observed at each season, and

24 they accounted for most of the dissimilarity between season and years. For most of the

25 species, the minimum density was observed during the autumn and winter of the second

26 year, which was the period characterized by the disturbance events, and this feature

27 explains the low similarity between the $2^{\text {nd }}$ year winter and the other sampling times

28 (Table 1-2, Fig. 3-4). Few species, such as the polychaete Nephtys hystricis, showed

29 similar density throughout the investigation. Other species, such as the amphipod

30 Pseudolirius kroyerii and the bivalve Nucula nucleus, were subjected to occasional

31 demographic blooms (Table 2). Yet, most of the inter-annual and season variability of

32 the community could be associated with the oscillation in the abundance of some of the 
1 most abundant and characteristic taxa such as Ampelisca diadema, Lumbrineris

2 latreillii, Corbula gibba Aricidea claudiae, Levinsenia gracilis and N. nucleus. The

3 first three species dominated the community and contributed to $65 \%$ of total

4 abundances. Overall, the six species account for about $80 \%$ of total abundances (Table $52)$.

6 The analysis of the Spearman rank correlation between the main univariate indices, the 7 density of the most important species and the environmental variables that gave the 8 highest correlation between the environmental and biological similarity matrix 9 (BIOENV), highlighted that: 1) the diversity and the number of taxa were not 10 significantly correlated; 2) there were negative correlations between the Shannon 11 Diversity Index, the total abundance and the density of $A$. diadema; 3 ) the density of $A$. 12 diadema was positively correlated with the density of L. latreillii, C. gibba, A. claudiae 13 and $L$. gracilis. With regard to the environmental variables: 1) a positive correlation 14 was found between transparency, temperature and the density of A. diadema, $L$. 15 latreillii and $C$. gibba; 2) the transparency was negatively related to diversity, oxygen 16 concentration and the Po flow; 3) the dissolved oxygen was inversely correlated with 17 the number of taxa, total abundance and densities of A. diadema and C. gibba (Tab. 3).

18 The number of taxa and Shannon diversity did not vary significantly between the two 19 years and among the different seasons (ANOVA for the number of taxa, log 20 transformation: Year, $\mathrm{F}=1.5, \mathrm{p}>0.26$; Season, $\mathrm{F}=1.5, \mathrm{p}>0.24$; ANOVA for Shannon 21 diversity: Year, $\mathrm{F}=4.6, \mathrm{p}>0.08$; Season, $\mathrm{F}=2.1, \mathrm{p}>0.11$ ). Yet, both indices exhibited 22 strong variation on a short temporal scale, among dates of the same season: the number 23 of taxa and diversity ranged from 14-35 and 1.5-2.7, respectively (Fig. 4).

24 The total abundance varied on both the inter-annual and seasonal scales, but most of the 25 variability was found between the two years (ANOVA, log transformation: Year, $26 \mathrm{~F}=8.8, \mathrm{p}<0.05 ;$ Season, $\mathrm{F}=3.0, \mathrm{p}<0.05)$. The highest densities were observed during the 27 first year, peaking in July 2005 with 12900 ind. $\mathrm{m}^{-2}$; in the second year, the 28 macrozoobenthic assemblages showed lower densities, with a minimum of about 400 29 ind. $\mathrm{m}^{-2}$ in February 2006 (Fig. 4). Despite the difference in the absolute values, the 30 trends in abundance were similar in the two years: it increased starting from the end of 31 spring, peaking in summer and then declining. These trends can be associated with the 
1 population dynamic of the dominant species, which exhibited different patterns of

2 temporal variability.

3 The total abundance was primarily related $\left(r_{s}=0.97\right.$, Table 3$)$ to the density of the 4 dominant amphipod $A$. diadema (mean density= 1840 ind. $\mathrm{m}^{-2} \pm 2560$ S.D.), which 5 varied on a seasonal level and, overall, between the two years (ANOVA, log 6 transformation: Year, F=7.9, $\mathrm{p}<0.05$; Season, $\mathrm{F}=3.1, \mathrm{p}<0.05$ ). During the first year, 7 between October 2004 and April 2005, the density of A. diadema population was 60081800 ind.m ${ }^{-2}$ (Fig. 4). Starting from May 2005, a rapid demographic increase was 9 observed: the density peaked in July 2005, with 11000 ind. $\mathrm{m}^{-2}$. Then the density 10 declined rapidly: in August and September it was about 3200 ind. $\mathrm{m}^{-2}$, and in October 112005 it was similar to those observed at the begin of the investigation (1100 ind $\left.\mathrm{m}^{-2}\right)$. 12 During the second year, from November 2005 and May 2006, a further decrease in the 13 density was observed, with a minimum of 25 ind. $\mathrm{m}^{-2}$ in March 2006. Between the end 14 of spring and the begin of summer, new recruitment events were observed. In fact, 15 between May and July 2006, density increased by an order of magnitude, from 270 ind. $16 \mathrm{~m}^{-2}$ to more than 2000 ind. $\mathrm{m}^{-2}$. Subsequently, the density of A. diadema was reduced to 17 about 500 ind. $\mathrm{m}^{-2}$ (Fig. 4).

18 The density of two other dominant species, $C$ gibba (mean density $=334$ ind. $\mathrm{m}^{-2} \pm 218$ $19 \mathrm{SD}$ ) and L. latreillii (mean density $=230$ ind. $\mathrm{m}^{-2} \pm 138 \mathrm{SD}$ ) varied only at seasonal 20 level (ANOVA for C. gibba density, log transformation: Year, $\mathrm{F}=0.5, \mathrm{p}>0.52$; Season, $21 \mathrm{~F}=7.3, \mathrm{p}<0.05$; ANOVA for L. latreillii density, $\log$ transformation: Year, $\mathrm{F}=0.3$, $22 \mathrm{p}>0.59$; Season, $\mathrm{F}=3.6, \mathrm{p}<0.05)$.

23 Between October 2004 and March 2005, the density of C. gibba was 250-330 ind.m ${ }^{-2}$ 24 (Fig. 4). Starting from May 2005, a rapid demographic increase was observed that resulted in a peak density in September 2005 (750 ind. $\left.\mathrm{m}^{-2}\right)$. Subsequently, during 26 autumn and winter, density decreased: a minimum of 25 ind. $\mathrm{m}^{-2}$ were found in March 2006. Starting from April 2006, density increased, peaking in July 2006 with 730 28 ind. $\mathrm{m}^{-2}$, and then declined in the following months (Fig. 4).

29 Also the lumbrinerid polychaete L. latreillii exhibited demographical variation with 30 season. The highest densities were observed during summer (400-500 ind. $\mathrm{m}^{-2}$ ), the 31 lowest in winter (60-180 ind. $\mathrm{m}^{-2}$ ) (Fig. 4). 
1 The pattern of temporal variation of the paraonid polychaete A. claudiae was quite

2 unusual (Fig. 4). At the beginning of the investigation, it was one of the most abundant

3 taxa (more than 1000 ind. $\mathrm{m}^{-2}$ ). Subsequently, its density declined and a minimum of

4 less than 20 ind. $\mathrm{m}^{-2}$ was found in February 2006. Then, the density increased during

5 spring and fall during summer 2005 (ANOVA, log transformation: Year, $\mathrm{F}=9.5$,

$6 \mathrm{p}<0.05$; Season, $\mathrm{F}=4.3, \mathrm{p}<0.01)$.

7 The dynamic of the other paraonid polychaete L. gracilis exhibited seasonal trends with

8 maximum densities during spring and minimum densities during autumn in both years

9 (ANOVA, log transformation: Year, F=2.4, p>0.17; Season, F=3.5, p<0.05; Fig. 4).

10 The ANOVA did not highlight any significant Year and Season effect on the density of 11 the bivalve $N$. nucleus (log transformation: Year, $\mathrm{F}=1.9, \mathrm{p}>0.21$; Season, $\mathrm{F}=1.6$, $12 \mathrm{p}>0.21$ ). From October 2004 to March 2006, the density of N. nucleus ranged from 25

13 to 170 ind. $\mathrm{m}^{-2}$ (with the exception of February 2006, when no specimens were found).

14 Then a demographic bloom was observed: the density peaked to more than 500 ind. $\mathrm{m}^{-2}$

15 in June 2004, then fell to 100 ind. $\mathrm{m}^{-2}$ in September 2006 (Fig. 4).

\section{Discussion}

18 Most of the previous investigations on the soft-bottom macrozoobenthos in the Northwestern Adriatic Sea adopted a sampling strategy with sampling intervals of three months or more (Moodley et al., 1998; Simonini et al., 2001, 2005b). In some cases, this approach can make it difficult to identify the seasonal patterns of variation in the benthic community (Occhipinti et al., 2005). The sampling strategy adopted in the present study provides some insight into the patterns of temporal variability and the role of biotic interactions and abiotic factors in determining community structure and the population densities of the most important species.

The macrozoobenthic assemblages at the CEBEB site showed clear seasonal trends.

27 Densities rose sharply at the end of spring/begin of summer, peaked in summer and then 28 strikingly declined, the lowest values being recorded during autumn and winter. Similar seasonal patterns were observed also at other North-western Mediterranean and Northern Adriatic shallow sites, and were relate to seasonal reproductive events, that were driven by the cyclical annual variation of most of the environmental variables

32 (Sardà et al., 1999; Simonini et al., 2005a). Multivariate and univariate analyses also 
1 highlighted significant inter-annual variability in the benthic community: in particular,

2 the total abundance and the density of one of the most abundant taxa, Ampelisca 3 diadema, were higher during the first year relative to the second year. The high inter4 annual variability of North-western Adriatic sea benthic assemblages was observed also 5 in previous investigations, and was attributed to several different perturbations, such as 6 Po river floods (Occhipinti Ambrogi et al., 2005), hypoxic/anoxic conditions (Moodley 7 et al, 1998, Simonini et al., 2004), thermal anomalies and severe storms (Simonini et al., 82005 a,b). Findings from a recent 6-years study suggested that the macrobenthic 9 community in the Emilia-Romagna coastal area was mainly determined by the onset of 10 very high Po river discharge values, which caused marked, short-term fall in the 11 macrozoobenthos density (Occhipinti Ambrogi et al., 2005). During the present study, 12 the flow of the Po was very low with respect to historical data (Montanari et al., 2004, 13 2005, 2006). Yet, a series of stress events occurred during the autumn 2005 and winter 14 2006: the hypoxic event associated with the anomalous high temperature of November 152005 , and the anomalous winter flood of February 2006 could be related to the 16 generalized reduction of density observed in the second year.

17 The most important species exhibited different patterns of temporal variation, in 18 response to seasonality and hydrological stress. The population number of the dominant 19 amphipod A. diadema was characterized by marked seasonal and inter-annual 20 variations. The preliminary analyses on the sex- and stage-structure of the population of 21 A. diadema at CEBEB highlighted that this species has a bivoltine cycle, with one winter- and one (or two) summer- generations (Grandi et al., 2007). The increased temperature and the high primary productivity at the end of winter promoted the gametogenesis and the reproduction of the winter generation, which occurred between May and June. The descendants build up the short-living summer generation, which matured early and reproduced during the summer, when the maximum density were observed, and gave rise to the winter generation that survived until the next year 28 (Grandi et al., 2007). We have no experimental data on the effect of burial and hypoxia on this species, but some recent $\mathrm{LC}_{50}$ 96h test performed with several inorganic and organic toxicants highlighted that $A$. diadema is one of the most sensitive amphipods to stress and pollution (Lera et al., 2007) and many amphipod species are susceptible to 
1 et al. (2005) observed that the density of A. diadema declined after severe Po river

2 outflows. It is possible that the stress condition that occurred between the first and 3 second year would have caused a reduction in the number of adults in the winter 4 generation and, subsequently, a lower recruitment into the summer generation in 5 comparison to the previous year.

6 The water temperature and hydrological variables that varied according to season also 7 affected the biological cycle of the bivalve Corbula gibba and the polychaetes 8 Lumbrineris latreillii and Levinsenia gracilis. These species were characterized by 9 seasonal variation with the same magnitude in the two years. Their recruitment took 10 place in spring, probably as a consequence of environmental (temperature-photoperiod) 11 stimuli, and then density declined during autumn. The stress events that took place 12 during autumn 2005 and winter 2006 did not have an appreciable effect on these 13 species, which can tolerate hypoxic conditions and high rates of sedimentation or 14 sediment re-suspension (Jensen, 1990; Diaz and Rosenberg, 1995; Moodley et al, 1988; 15 Makra and Nicolaidou, 2000).

16 The population dynamics of the polychaete Aricidea claudiae and the bivalve Nucula 17 nucleus were quite unusual, because they were very abundant only at the beginning or at 18 the end of the investigation, respectively. Perhaps, the exceptionally low Po river 19 discharge and the lack of severe flood events during the investigation could have had a 20 negative effect on A. claudiae: in fact, Salen-Picard et al. (2002) observed that this opportunistic short-lived species exhibited high short-term peaks in density a few 22 months after Rhone flooding events in the Gulf of Lion. Most information on the 23 biology of $N$. nucleus referred to Northern European populations (see Holmes et al., 24 2002). This species spawned on alternate years and adopted an "exploitative function strategy, i.e. maturation is maximal in the absence of nutritional limits" (Holmes et al., 2002). If we assume that also the Northern Adriatic population exhibits a similar strategy, the peak in the abundance of $N$. nucleus observed in spring and early summer 2006 could be associated with a recruitment event that occurred in the second year only, favoured by the peak of primary productivity recorded during winter 2006. Further analyses on the life cycle, population dynamic and secondary productivity will be carried out in order to confirm the speculation and hypotheses on the effects of intra- 
1 and inter-annual variability of the abiotic condition on the most abundant and

2 characteristics species at the investigated area.

3 Among the biotic factors, cases of biotic interaction between species have been reported

4 for the North-western Adriatic Sea (Prevedelli et al., 2001). The occurrence of inter-

5 specific competition between A. diadema and C. gibba was suggested by Moodley et al.

6 (1998), who observed that $C$. gibba abundance may be negatively affected by the

7 presence of large populations of Ampelisca. They consider the two species as

8 suspension-feeders, which can compete for food supply; moreover, they suggested that

9 dense stands of Ampelisca, which build tubes in the more superficial layers of sediment,

10 would occupy space and influence the structure and density of the community deeper

11 down (Dauvin, 1988; Dauvin \& Bellan-Santini, 1990). Also, Occhipinti Ambrogi et al.

12 (2005) reported that A. diadema replaced $C$. gibba as the dominant species, especially

13 during and after periods of low river discharge. Our results did not support the existence

14 of negative effects of $A$. diadema on $C$. gibba. In fact we observed a positive correlation

15 between the densities of the two species (Table 3). In both field and laboratory

16 conditions, A. diadema and C. gibba did not segregate in the space, occurring randomly

17 mixed in the sediment surface, and exhibited generalist trophic behaviour, acting as

18 facultative suspension- or sediment-surface feeders (Simonini et al., 2004; Grandi et al.,

19 2007, unpublished data). Moreover, the density of Ampelisca diadema in the North-

20 western Adriatic Sea did not appear to be so high as to allow the bio-construction of the

21 dense carpets observed in the North-eastern Atlantic, where the ampeliscid amphipods

22 can reach density of an order of magnitude greater (Bellan-Santini and Dauvin, 1988;

23 Poggiale and Dauvin, 2001). Manipulative experimentations are required to establish

24 the occurrence and the magnitude of the inter-specific competition between the two 25 species.

26 According with Occhipinti Ambrogi et al. (2005), the incidence of the $1^{\text {st }}$ and $2^{\text {nd }}$ order 27 opportunistic species, which were dominant in the 1980s and early 1990s communities, 28 seemed to be reduced in recent years. During the study period also, the average density 29 of the bivalve $C$. gibba was three times lower relative to those observed from the 1980s 30 until 2000, when dense populations with more than 1000-1500 ind. $\mathrm{m}^{-2}$ were 31 extensively reported (Crema et al., 1991; Moodley et al., 1998; Prevedelli et al., 2001, 32 2004). On the other hand, the abundance of $A$. diadema, which was rare until the late 
1 1980s ( $<5 \%$ of total abundances), seemed to increase starting from the mid 1990s until

2 recent years, when densities of more than 2000-10000 ind. $\mathrm{m}^{-2}$ were observed (Simonini

3 et al., 2005b; Occhipinti Ambrogi et al., 2005). If we assume that the contribution of

4 inter-specific relationship between A. diadema and C. gibba is negligible, the decline of

5 the opportunistic species in favour of the sensitive ones could be related to the variation

6 of the Po and Adriatic Sea hydrographical regimes. A tendency towards a reduction in

7 river inputs due to the decreases in rainfall and an increase in sea water temperature has

8 emerged in recent years (Russo, 2002; Montanari et al., 2004, 2005, 2006). This trend,

9 which is generalized for the whole Mediterranean region and should be reinforced in the

10 near future, as a consequence of climatic changes $\left(4^{\text {th }}\right.$ IPPC report,

11 http://www.ipcc.ch/ipccreports/index.htm), could lead to two different scenarios. If no

12 eutrophication events and hydrological disturbance occurred, the reduction of river flow

13 could favour the occurrence of more stable physical conditions on the bottom and the

14 establishment of benthic communities with a higher degree of structural complexity

15 and/or a reduction of opportunistic-tolerant species in favour of more sensitive species

16 (Occhipinti et al., 2005). On the other hand, increased surface temperatures, altered

17 circulation, and precipitation changes could increase the thermal stratification and

18 amplify the frequency and extent of bottom water hypoxia or anoxia in late summer and

19 autumn (Russo et al, 2002), with strong effects on community density and structure. If

20 the beneficial impacts of the reduction of river flood prevailed, the establishment of

21 communities at more mature successional stage would be favoured.

22

\section{Acknowledgements}

24 The authors thank the crew of the oceanographic M/S "Daphne II" (Struttura 25 Oceanografica Daphne, ARPA Emilia-Romagna), Mr. Marco Papperini and Mr. Dino 26 Pagan, and Dr. Katie Henry for English language corrections. We would like to thank 27 the Editor and the three anonymous reviewers of the paper for their helpful advice.

References

30 Bellan-Santini, D., Dauvin, J.C., 1988. Eléments de synthèse sur les Ampelisca du nord31 est Atlantique. Crustaceana, 13, 20-60. 
1 Borja, A., Dauer, D.M., 2008. Assessing the environmental quality status in estuarine

2 and coastal systems: Comparing methodologies and indices. Ecological Indicators, 8, $3331-337$.

4 Bucci, D., Mengarelli, C., Venanzini, C., Petrelli, C., Di Marino, L., 1992. A year 5 monitoring of marine eutrophication on the coast of Ancona. In Vollenweider, R.A.,

6 Marchetti, R., Viviani, R. (Eds). Marine Coastal Eutrophication. Elsevier, Amsterdam, $7 \quad 411-418 \mathrm{pp}$.

8 Cavallini, F., Iotti, M., Simonini, R., 2005. Evoluzione dei popolamenti 9 macrozoobentonici dell'Adriatico Settentrionale. I. Analisi dei dati storici di Aristocle 10 Vatova (1934-1936). Atti della Società dei Naturalisti e Matematici Modena, 135, 14511154.

12 Clarke, K.R., Ainsworth, M., 1993. A method of linking multivariate community 13 structure to environmental variables. Marine Ecology Progress Series, 92, 205-219. 14 Clarke, K.R., Warwick, R.M., 2001. Change in marine communities: an approach to 15 statistical analysis and interpretation, $2^{\text {nd }}$ edition, Primer-E, Plymouth, UK.

16 Crema, R., Castelli, A., Prevedelli, D., 1991. Long term eutrophication effects on 17 macrofaunal communities in the Northern Adriatic Sea. Marine Pollution Bulletin, 22, $18 \quad 503-508$.

19 Dauvin, J.C., 1988. Biologie, dynamique, et production de populations de crustacés 20 amphipodes de la Manche occidentale. 1. Ampelisca tenuicornis (Liljeborg). Journal of 21 Experimental Marine Biology and Ecology, 118, 55-84.

22 Dauvin, J.C., Bellan-Santini, D., 1990. An overview of the amphipod genus Haploops 23 (Ampeliscidae). Journal of the Marine Biological Association of the United Kingdom, 24 70, 887-903.

25 Diaz, R. J., Rosenberg, R., 1995. Marine benthic hypoxia: a review of its ecological 26 effects and the behavioural responses of benthic macrofauna. Oceanography and Marine 27 Biology Annual Revue, 33, 245-303.

28 Grandi, V., Montanari, G., Lera, S., Simonini, R., 2007 Distribuzione, ciclo biologico e 29 comportamento dell'anfipode Ampelisca diadema, una possibile specie-test per saggi 30 ecotossicologici su sedimenti marini. Biologia Marina Mediterranea, 14(1), 145-147. 
1 Grémare, A., Amouroux, J.M., Vétion, G., 1998. Long-term comparison of

2 macrobenthos within the soft bottoms of the Bay of Banyuls-sur-mer (northwestern

3 Mediterranean Sea) Neth Journal of Sea Research, 40, 281-302

4 Gray, J.S, Wu, R.S.S, Or, Y.Y., 2002. Effects of hypoxia and organic. enrichment on

5 the coastal marine environment. Marine Ecology Progress Series, 238,249-279

6 Holmes, S.P., Miller, N., Weber, A., 2002. The respiration and hypoxic tolerance of

$7 \quad$ Nucula nitidosa and N. nucleus: factors responsible for determining their distribution?.

8 Journal of the Marine Biological Association of the United Kingdom, 82(6), 971-981.

9 Jensen, J.J., 1990. Increased abundance and growth of the suspension-feeding bivalve

10 Corbula gibba in a shallow part of eutrophic Limfjord, Denmark. Neth Journal of Sea

11 Research, 27, 101-108.

12 Johansson, B. (1997). Behavioural response to gradually declining oxygen

13 concentration by Baltic Sea macrobenthic crustaceans. Marine Biology 129, 71-78.

14 Justic, D., 1987. Long term eutrophication of the Northern Adriatic Sea. Marine

15 Pollution Bulletin, 18, 281-283.

16 Justic, D., Rabalais, N. N., Turner, R. E., Dortch, Q., 1995. Changes in nutrient

17 structure of river-dominated coastal waters: stechiometric nutrient balance and its

18 consequences. Estuarine, Coastal and Shelf Science, 40, 339-356.

19 Labrune, C., Grémare, A., Guizien, K., Amouroux, J.M., 2007. Long-term comparison

20 of soft bottom macrobenthos in the Bay of Banyuls-sur-Mer (north-western

21 Mediterranean Sea): A reappraisal. Journal of Sea Research, 58, 125-143.

22 Largier, J.L., 1993. Estuarine fronts: how important are they? Estuaries, 16, 1-11.

23 Lera, S., Simonini, R., Montanari, G., Dentone, L., Macchia, S., 2007. Sensitivity of

24 Ampelisca diadema (Crustacea: Amphipoda) to organic and inorganic toxicants in test

25 of acute toxicity. Biologia Marina Mediterranea, 14(1),148-151.

26 López-Jamar, E., González, G., Mejuto, J., 1986. Temporal changes of community

27 structure and biomass in two subtidal macroinfaunal assemblages in La Coruña Bay,

28 NW Spain. Hydrobiologia, 142, 137-150.

29 Makra, A., Nicolaidou, A., 2000. Benthic communities of the inner Argolikos Bay.

30 Belgian Journal of Zoology 130(Suppl.), 63-69. 
1 Marchetti, R., Verna, N., 1992. Quantification of the phosphorous and nitrogen loads in

2 the minor rivers of the Emilia-Romagna coast (Italy). In Vollenweider, R.A., Marchetti,

3 R., Viviani, R. (Eds). Marine Coastal Eutrophication. Elsevier, Amsterdam, 315-336 pp.

4 Matteucci, M., Frascari, F., 1997. Fluxes of suspended materials in the north Adriatic

5 sea (Po prodelta area). Water, Air and Soil Pollution, 99, 557-572.

6 Montanari, G, Rinaldi, A, Ghetti, A, Ferrari, CR, Mazziotti, C, Serra, S., 2005.

7 Eutrofizzazione delle acque costiere dell'Emilia-Romagna Rapporto annuale 2004.

8 Agenzia regionale prevenzione e ambiente dell'Emilia-Romagna, Bologna, Italy

9 Montanari, M., Pinardi, N., 2006. The currents of Emilia-Romagna coastal strip during

10 the period 1995-2002. Quaderni di Arpa, Arpa Linea Editoriale, Bologna, Italy.

11 Montanari, G., Rinaldi, A., Ghetti, A., Ferrari C.R., Mazziotti, C., Serra, S., 2006.

12 Eutrofizzazione delle acque costiere dell'Emilia-Romagna Rapporto annuale 2005.

13 Agenzia regionale prevenzione e ambiente dell'Emilia-Romagna, Bologna, Italy

14 Montanari, G., Rinaldi, A., Ghetti, A., Ferrari C.R., Mazziotti, C., Serra, S., 2007.

15 Eutrofizzazione delle acque costiere dell'Emilia-Romagna Rapporto annuale 2006.

16 Agenzia regionale prevenzione e ambiente dell'Emilia-Romagna, Bologna, Italy

17 Moodley, L., Heip, C.H.R., Middelburg, J.J., 1998. Benthic activity in sediments of the

18 northwestern Adriatic Sea: sediment oxygen consuption, macro-and meiofauna

19 dynamics. Neth Journal of Sea Research, 40, 263-280.

20 Morrisey, D.J., Underwood, A.J., Howitt, L., Stark, J.S., 1992. Temporal variation in

21 soft-sediment benthos. Journal of Experimental Marine Biology and Ecology, 164(2),

22 233-245.

23 Occhipinti-Ambrogi, A., Savini, D., Forni, G., 2005. Macrobenthos community 24 structural changes off Cesenatico coast (Emilia Romagna, Northern Adriatic), a six-year 25 monitoring programme. Science of the Total Environment, 353, 317-328.

26 Pérès, J.M., Picard, J., 1964. Nouveau manuel de bionomie benthique de la Mer 27 Méditérranée. Recueil de Traveaux de la Stationne Marine de Endoume 31 (47), 1-124.

28 Poggiale, J.C., Dauvin, J.C., 2001. Long-term dynamics of three benthic Ampelisca 29 (Crustacea-Amphipoda) populations from the Bay of Morlaix (western English 30 Channel) related to their disappearance after the 'Amoco Cadiz' oil spill. Marine 31 Ecology Progress Series, 214, 201-209. 
1 Prevedelli, D., Simonini, R., Ansaloni, I., 2001. Relationship of non-specific

2 commensalism in the colonization of the deep layers of sediment. Journal of the Marine

3 Biological Association of the United Kingdom, 81, 897-901.

4 Rosenberg, R., Loo, L.O., Möller, P., 1992. Hypoxia, salinity and temperature as

5 structuring factors for marine benthic communities in a eutrophic area. Neth Journal of

6 Sea Research, 30, 121-129.

7 Russo, A., Rabitti, S., Bastianini, M. 2002. Decadal Climatic Anomalies in the Northern

8 Adriatic Sea Inferred from a New Oceanographic Data Set. Marine Ecology, 23, 340 9351.

10 Russo, A., Maccaferri, S., Djakac, T., Precali, R., Degobbis, D., Deserti, M. 2005.

11 Meteorological and oceanographic condition in the northern Adriatic Sea during the 12 period June 1999- July 2002: influence on the mucilage phenomenon. Science of the 13 Total Environment, 353, 24-38.

14 Salen-Picard, C., Darnaude, A.M., Arlhac D., Harmelin-Vivien, M.L., 2002.

15 Fluctuations of macrobenthic populations: a link between climate-driven river run-off

16 and sole fishery yields in the Gulf of Lions. Oecologia, 133, 380-388.

17 Salen-Picard, C., Arlhac, D., Alliot, E. 2003. Responses of a Mediterranean soft bottom 18 community to short-term (1993-1996) hydrological changes in the Rhone river. Marine 19 Environmental Research, 55, 409-427.

20 Sardà, R., Pinedo, S., Martin, D., 1999. Seasonal dynamics of macroinfaunal key 21 species inhabiting shallow soft-bottoms in the Bay of Blanes (NW Mediterranean). Acta 22 Oecologica, 20, 315-326.

23 Simonini, R., Ansaloni, I., Bonvicini Pagliai, A.M., Prevedelli, D. 2004. Organic 24 enrichment and structure of the macrozoobenthic community in the northern Adriatic 25 Sea in an area facing Adige and Po mouths. ICES Journal of Marine Science, 61, 87126881.

27 Simonini, R., Ansaloni, I., Bonvicini Pagliai, A.M., Cavallini, F., Iotti, M., Mauri, M., 28 Montanari, G., Preti, M., Rinaldi, A., Prevedelli, D., 2005a. The effects of sand 29 extraction on the macrobenthos of a relict sands area (northern Adriatic Sea): results 12 30 months post-extraction. Marine Pollution Bulletin, 50, 768-777.

31 Simonini, R., Ansaloni, I., Cavallini, F., Graziosi, F., Iotti, M., Massamba N'Siala, G., 32 Mauri, M., Montanari, G., Preti, M., Prevedelli D., 2005b. Effects of long-term 
1 dumping of harbor-dredged material on macrozoobenthos at disposal sites along the

2 Emilia-Romagna coast (Northern Adriatic Sea, Italy). Marine Pollution Bulletin, 50, $3 \quad 1595-1605$.

4 Simonini, R., Ansaloni, I., Bovini, P., Grandi, V., Graziosi, F., Iotti, M., Massamba

5 N'Siala, G., Mauri, M., Montanari, G., Preti, M., De Nigris, N., Prevedelli D., 2007.

6 Recolonization and recovery dynamics of the macrozoobenthos after sand extraction in

7 relict sand bottoms of the Northern Adriatic Sea. Marine Environmental Research, 64/5, $8 \quad 574-589$.

9 Vatova, A., 1949. La fauna bentonica dell'Alto e Medio Adriatico. Nova Thalassia, 1, $10 \quad 1-110$.

11 Vollenweider, R. A., Marchetti, R., Viviani, R. 1992. Eutrophication, structure and 12 dynamics of a marine coastal system: result of ten-year monitoring along the Emilia13 Romagna coast (Northwestern Adriatic Sea). In Vollenweider, R.A., Marchetti, R., 14 Viviani, R. (Eds). Marine Coastal Eutrophication. Elsevier, Amsterdam, 63-106 pp. 
1 Table 1. Within-season Bray-Curtis similarities (diagonals) and between-season dissimilarities (under the diagonals), estimated for the two

2 years of sampling ( $2^{\text {nd }}$ root transformed data) by means of SIMPER analysis. The dissimilarity values were given together with the 3 corresponding R statistic value, obtained from the pair-wise one-way ANOSIM comparison test between season. Significant R values are

4 highlighted in bold ( $\mathrm{p}<0.05$ for the global test, $\mathrm{R}_{\text {pairwise test }}<\mathrm{R}_{\text {global test }}$ for pair-wise comparison between season of the same year, Clarke 5 and Warwick, 2001).

6

\begin{tabular}{|c|c|c|c|c|}
\hline & \multicolumn{3}{|c|}{$1^{\text {st }}$ year $($ ANOSIM among Seasons, $\mathbf{R}=\mathbf{0 . 5 0})$} & \multirow[b]{2}{*}{ Su $1^{\text {st }}$} \\
\hline & $\mathrm{Au} 1^{\mathrm{st}}$ & $\mathrm{Wi} 1^{\mathrm{st}}$ & $\mathrm{Sp} 1^{\mathrm{st}}$ & \\
\hline $\mathrm{Au} 1^{\mathrm{st}}$ & 72 & & & \\
\hline Wi $1^{\text {st }}$ & $31 ; \mathrm{R}=0.15$ & 71 & & \\
\hline $\mathrm{Sp} 1^{\mathrm{st}}$ & $37 ; \mathbf{R}=\mathbf{0 . 5 6}$ & $36 ; R=0.15$ & 65 & \\
\hline $\mathrm{Su} 1^{\text {st }}$ & $38 ; R=0.96$ & $38 ; R=0.74$ & $36 ; \mathrm{R}=0.44$ & 71 \\
\hline \multicolumn{5}{|c|}{$2^{\text {nd }}$ year (ANOSIM among Season, $\mathbf{R}=\mathbf{0 . 5 2}$ ) } \\
\hline & $\mathrm{Au} 2^{\text {nd }}$ & Wi $2^{\text {nd }}$ & $\operatorname{Sp} 2^{\text {nd }}$ & $\mathrm{Su} 2^{\text {nd }}$ \\
\hline $\mathrm{Au} 2^{\text {nd }}$ & 78 & & & \\
\hline Wi $2^{\text {nd }}$ & $52 ; R=0.63$ & 50 & & \\
\hline $\operatorname{Sp} 2^{\text {nd }}$ & $38 ; R=0.56$ & $46 ; \mathrm{R}=0.26$ & 65 & \\
\hline $\mathrm{Su} 2^{\text {nd }}$ & $45 ; R=0.93$ & $55 ; R=0.67$ & 41; $R=0.67$ & 64 \\
\hline
\end{tabular}

7 
1 Table 2. Seasonal density (mean \pm standard deviation) of the species that contributes 1) at least $3 \%$ to the total abundances observed at 2 each season; 2) to more than $60 \%$ of the dissimilarity between sampling years and season (SIMPER, $2^{\text {nd }}$ root transformed data). Class (C.): $3 \mathrm{~A}=$ amphipods $; \mathrm{B}=$ bivalves $; \mathrm{G}=$ gastropods; $\mathrm{P}=$ polychaetes.

4

\begin{tabular}{|c|c|c|c|c|c|c|c|c|c|}
\hline C. & taxa & $\mathrm{Au} 1^{\mathrm{st}}$ & $\mathrm{Wi} 1^{\mathrm{st}}$ & $\mathrm{Sp} 1^{\mathrm{st}}$ & $\mathrm{Su} 1^{\mathrm{st}}$ & $\mathrm{Au} 2^{\text {nd }}$ & $\mathrm{Wi} 2^{\text {nd }}$ & Sp $2^{\text {nd }}$ & Su $2^{\text {nd }}$ \\
\hline $\mathrm{P}$ & Aricidea claudiae & $931 \pm 238$ & $581 \pm 246$ & $358 \pm 36$ & $300 \pm 33$ & $239 \pm 25$ & $69 \pm 71$ & $206 \pm 38$ & $69 \pm 73$ \\
\hline $\mathrm{P}$ & Euclymene oerstedii & $44 \pm 41$ & $36 \pm 34$ & $22 \pm 25$ & $19 \pm 13$ & $0 \pm 0$ & $11 \pm 10$ & $11 \pm 13$ & $0 \pm 0$ \\
\hline $\mathrm{P}$ & Glycera tridactyla & $31 \pm 38$ & $11 \pm 10$ & $8 \pm 8$ & $11 \pm 10$ & $3 \pm 5$ & $6 \pm 10$ & $14 \pm 13$ & $8 \pm 8$ \\
\hline $\mathrm{P}$ & Lumbrineris latreilli & $242 \pm 169$ & $192 \pm 167$ & $303 \pm 46$ & $417 \pm 90$ & $78 \pm 84$ & $158 \pm 93$ & $267 \pm 123$ & $331 \pm 84$ \\
\hline $\mathrm{P}$ & Magelona alleni & $75 \pm 43$ & $56 \pm 5$ & $31 \pm 5$ & $11 \pm 13$ & $42 \pm 0$ & $17 \pm 17$ & $17 \pm 14$ & $17 \pm 17$ \\
\hline $\mathrm{P}$ & Monticellina dorsobranchialis & $331 \pm 200$ & $628 \pm 427$ & $789 \pm 740$ & $142 \pm 130$ & $47 \pm 10$ & $14 \pm 5$ & $56 \pm 10$ & $0 \pm 0$ \\
\hline $\mathrm{P}$ & Neanthes succinea & $0 \pm 0$ & $0 \pm 0$ & $28 \pm 35$ & $0 \pm 0$ & $0 \pm 0$ & $6 \pm 10$ & $0 \pm 0$ & $0 \pm 0$ \\
\hline $\mathrm{P}$ & Nephtys hystricis & $33 \pm 14$ & $36 \pm 34$ & $56 \pm 32$ & $33 \pm 17$ & $47 \pm 10$ & $25 \pm 8$ & $64 \pm 38$ & $78 \pm 41$ \\
\hline $\mathrm{P}$ & Levinsenia gracilis & $106 \pm 47$ & $144 \pm 167$ & $247 \pm 32$ & $147 \pm 67$ & $72 \pm 13$ & $31 \pm 29$ & $203 \pm 43$ & $28 \pm 13$ \\
\hline $\mathrm{P}$ & Prionospio cirrifera & $122 \pm 71$ & $119 \pm 64$ & $44 \pm 55$ & $78 \pm 46$ & $33 \pm 0$ & $14 \pm 24$ & $6 \pm 10$ & $0 \pm 0$ \\
\hline $\mathrm{P}$ & Sigambra tentaculata & $69 \pm 70$ & $22 \pm 10$ & $19 \pm 17$ & $22 \pm 13$ & $0 \pm 0$ & $8 \pm 8$ & $6 \pm 5$ & $3 \pm 5$ \\
\hline A & Ampelisca diadema & $972 \pm 263$ & $1522 \pm 211$ & $3961 \pm 3755$ & $5747 \pm 4362$ & $647 \pm 483$ & $125 \pm 145$ & $564 \pm 551$ & $1186 \pm 1007$ \\
\hline A & Pseudolirius kroyerii & $0 \pm 0$ & $3 \pm 5$ & $0 \pm 0$ & $3 \pm 5$ & $0 \pm 0$ & $14 \pm 17$ & $6 \pm 5$ & $361 \pm 465$ \\
\hline B & Abra alba & $14 \pm 13$ & $53 \pm 25$ & $3 \pm 5$ & $61 \pm 63$ & $31 \pm 25$ & $47 \pm 21$ & $106 \pm 67$ & $78 \pm 27$ \\
\hline B & Corbula gibba & $361 \pm 142$ & $278 \pm 49$ & $156 \pm 92$ & $700 \pm 50$ & $297 \pm 100$ & $56 \pm 27$ & $361 \pm 321$ & $464 \pm 64$ \\
\hline G & Hyala vitrea & $22 \pm 38$ & $3 \pm 5$ & $3 \pm 5$ & $14 \pm 24$ & $14 \pm 10$ & $8 \pm 14$ & $6 \pm 5$ & $83 \pm 117$ \\
\hline B & Mysella bidentata & $131 \pm 91$ & $22 \pm 38$ & $17 \pm 14$ & $119 \pm 145$ & $56 \pm 59$ & $36 \pm 43$ & $3 \pm 5$ & $0 \pm 0$ \\
\hline B & Nucula nucleus & $56 \pm 17$ & $56 \pm 38$ & $42 \pm 30$ & $33 \pm 17$ & $92 \pm 71$ & $31 \pm 27$ & $225 \pm 276$ & $203 \pm 142$ \\
\hline B & Paphia aurea & $3 \pm 5$ & $3 \pm 5$ & $0 \pm 0$ & $72 \pm 86$ & $44 \pm 13$ & $0 \pm 0$ & $3 \pm 5$ & $3 \pm 5$ \\
\hline $\mathrm{B}$ & Scapharca inaequivalvis & $19 \pm 13$ & $0 \pm 0$ & $3 \pm 5$ & $92 \pm 112$ & $192 \pm 171$ & $22 \pm 32$ & $31 \pm 17$ & $25 \pm 8$ \\
\hline
\end{tabular}

5

6 
1 Table 3. Spearman correlation between the main univariate indices, the density of most important species and the environmental variables 2 that gave the high correlation between the environmental and biological similarity matrix (BIOENV). Significant correlations were 3 highlighted in bold $\left(\mathrm{n}=24, \mathrm{r}_{\mathrm{s}}\right.$ crit $\left.=0.41\right)$. Diversity: Shannon Index; Tot Ab: Total Abundance; Density of 6 main species: Ampelisca 4 diadema, Corbula gibba, Lumbrineris latreilli, Aricidea assimilis, Levinsenia gracilis, Nucula nucleus; Transparency: Secchi disk.

5

\begin{tabular}{|c|c|c|c|c|c|c|c|c|c|c|c|c|}
\hline & Taxa & Tot $\mathrm{Ab}$ & Diversity & A. diadema & C. gibba & L. latreilli & A. assimilis & L.gracilis & N. nucleus & Transparency & Temperature & {$\left[\mathrm{O}_{2}\right]$} \\
\hline Total Abundance & 0.36 & & & & & & & & & & & \\
\hline Diversity & 0.23 & -0.71 & & & & & & & & & & \\
\hline A. diadema & 0.24 & 0.97 & -0.83 & & & & & & & & & \\
\hline C. gibba & 0.34 & 0.61 & -0.37 & 0.56 & & & & & & & & \\
\hline L. latreilli & 0.18 & 0.66 & -0.39 & 0.55 & 0.60 & & & & & & & \\
\hline A. assimilis & 0.54 & 0.61 & -0.15 & 0.53 & 0.13 & 0.13 & & & & & & \\
\hline L.gracilis & 0.41 & 0.55 & -0.13 & 0.41 & 0.11 & 0.49 & 0.58 & & & & & \\
\hline N. nucleus & 0.38 & 0.08 & 0.15 & 0.02 & 0.48 & 0.27 & -0.09 & 0.01 & & & & \\
\hline Transparency & 0.24 & 0.58 & -0.41 & 0.54 & 0.52 & 0.36 & 0.23 & 0.41 & 0.21 & & & \\
\hline Temperature & 0.28 & 0.50 & -0.37 & 0.46 & 0.77 & 0.51 & 0.01 & 0.07 & 0.32 & 0.58 & & \\
\hline$\left[\mathrm{O}_{2}\right]$ & -0.42 & -0.47 & 0.20 & -0.48 & -0.67 & -0.37 & -0.25 & -0.09 & -0.13 & -0.42 & -0.87 & \\
\hline Po Flow & 0.09 & -0.31 & 0.38 & -0.37 & -0.32 & -0.39 & 0.27 & -0.12 & -0.20 & -0.41 & -0.29 & 0.01 \\
\hline
\end{tabular}

8 


\section{$1 \quad$ Legends of figures}

2

3 Fig. 1. Location of the sampling station CEBEB (Cesenatico-Bellaria Bianco) (from

4 Simonini et al., 2005b, modified) and Po river discharge in the period October 2004 -

5 September 2006 (from Montanari et al, 2004, 2005, 2006). In the Po river flow plot, the

6 main storm events (wave height $>3 \mathrm{~m}$ ) and the occurrence of hypoxic conditions are

7 indicated by the grey bars and the asterisk, respectively.

9 Fig. 2. Chemical-physical variables of bottom sea water, \% (silt+clay) and \%TOC of 10 sediment from CEBEB in the period October 2004 - September 2006. Several 11 disturbance events during November 2005-March 2006 are highlighted in grey.

13 Fig. 3. 2D-nMDS ordinations of macrozoobenthic communities at CEBEB site during 14 the period October 2004 - September 2006 (2 $2^{2 \mathrm{~d}}$-root transformed abundance data). 15 Symbols: Sampling year $\left(\right.$ circles $=1^{\text {st }}$ year; Triangles $=2^{\text {nd }}$ year); Season (white $=$ winter; 16 light grey=spring; black=summer; dark grey=autumn).

18 Fig. 4. Main ecological indices (total abundances, number of taxa and Shannon 19 diversity) and density of the dominant species Ampelisca diadema, Corbula gibba and 20 Lumbrineris latreillii, and the three common species Aricidea claudiae, Levinsenia 21 gracilis and Nucula nucleus from CEBEB during the period October 2004 - September 22 2006. Note the different scales for the total abundance and species density plots. Several 23 disturbance events during November 2005 - March 2006 are highlighted in grey. 


\section{ACCEPTED MANUSCRIPT}
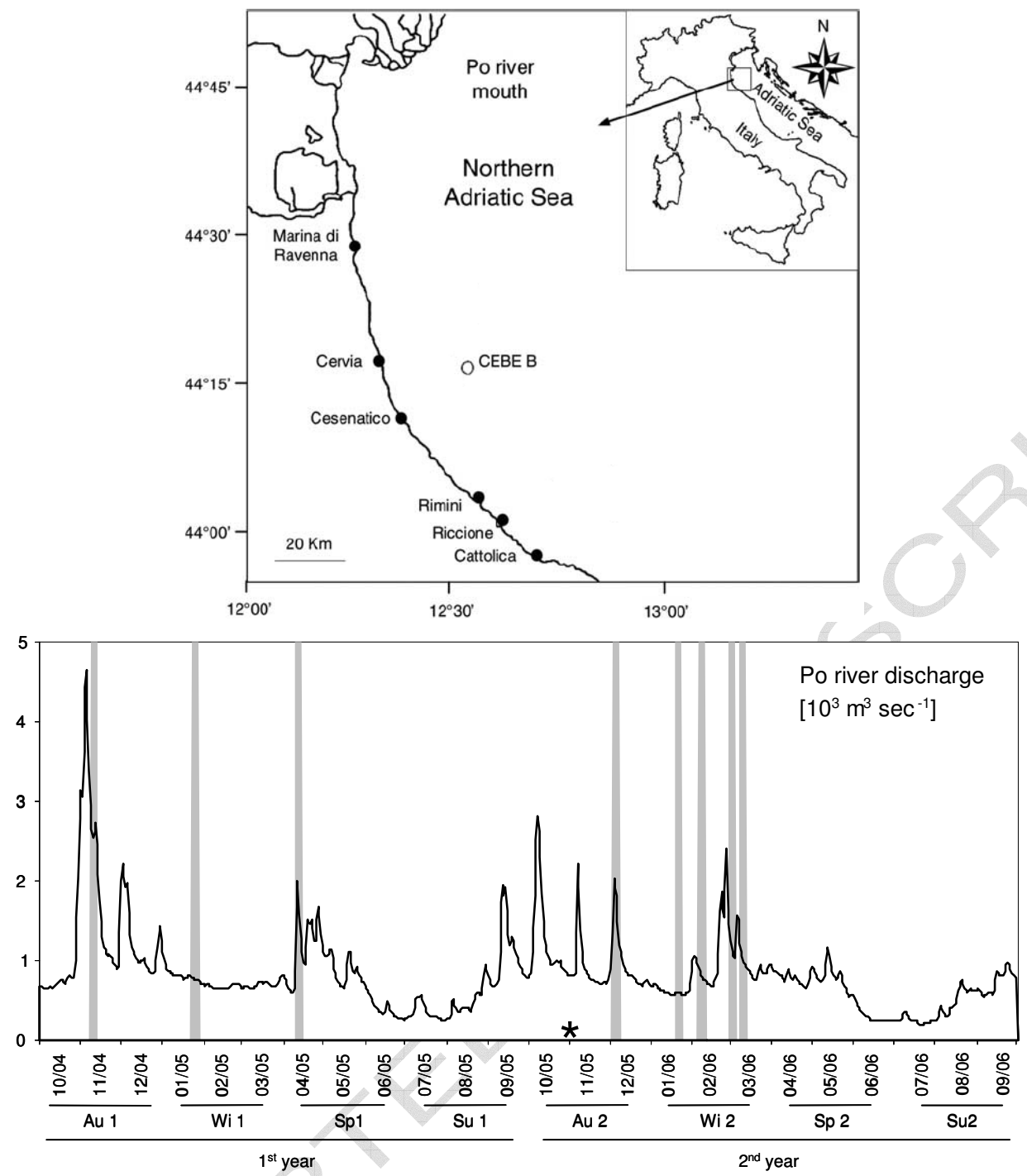

Massamba N'Siala et al. FIGURE 1 


\section{ACCEPTED MANUSCRIPT}
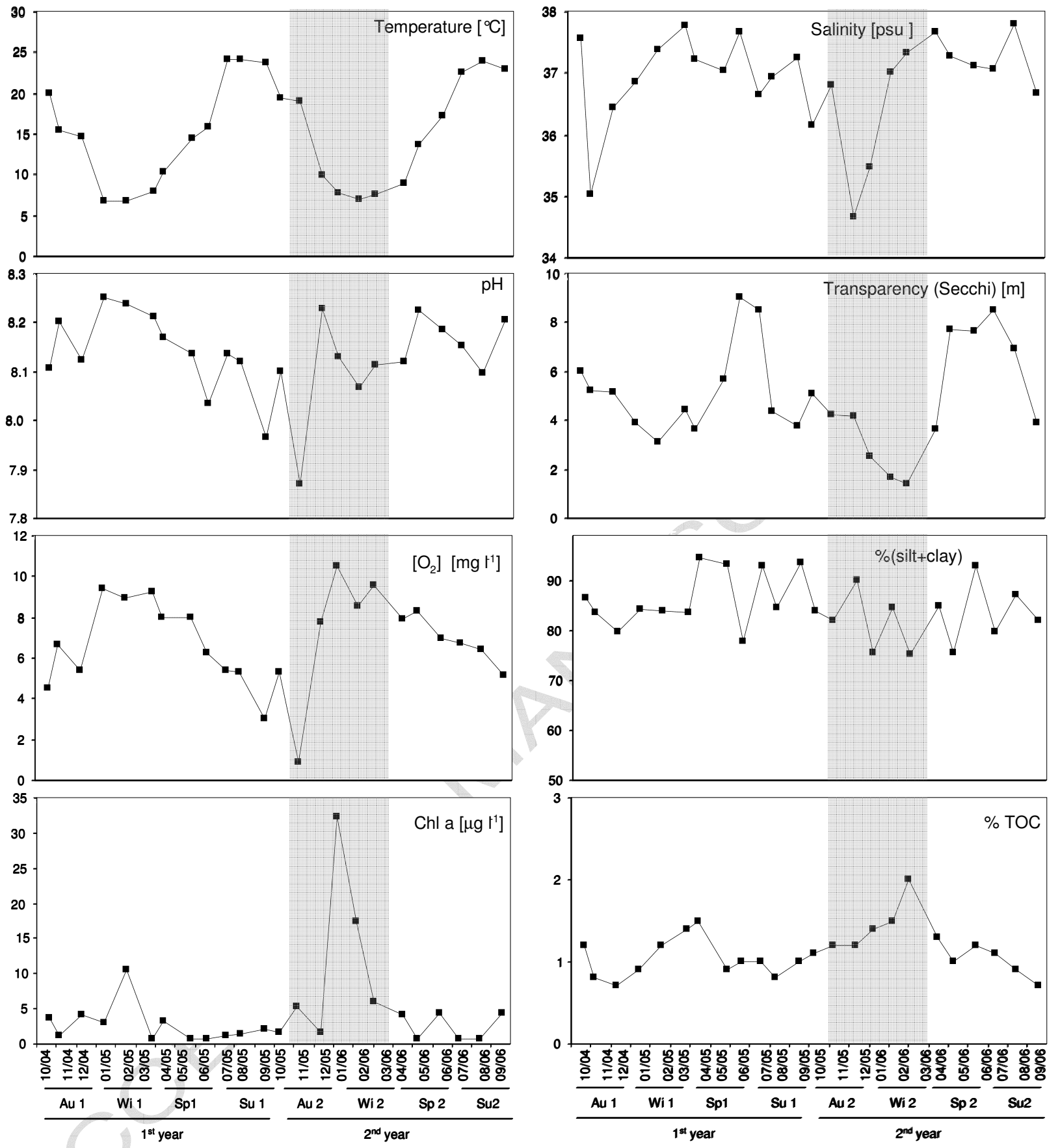

Massamba N'Siala et al. FIGURE 2 


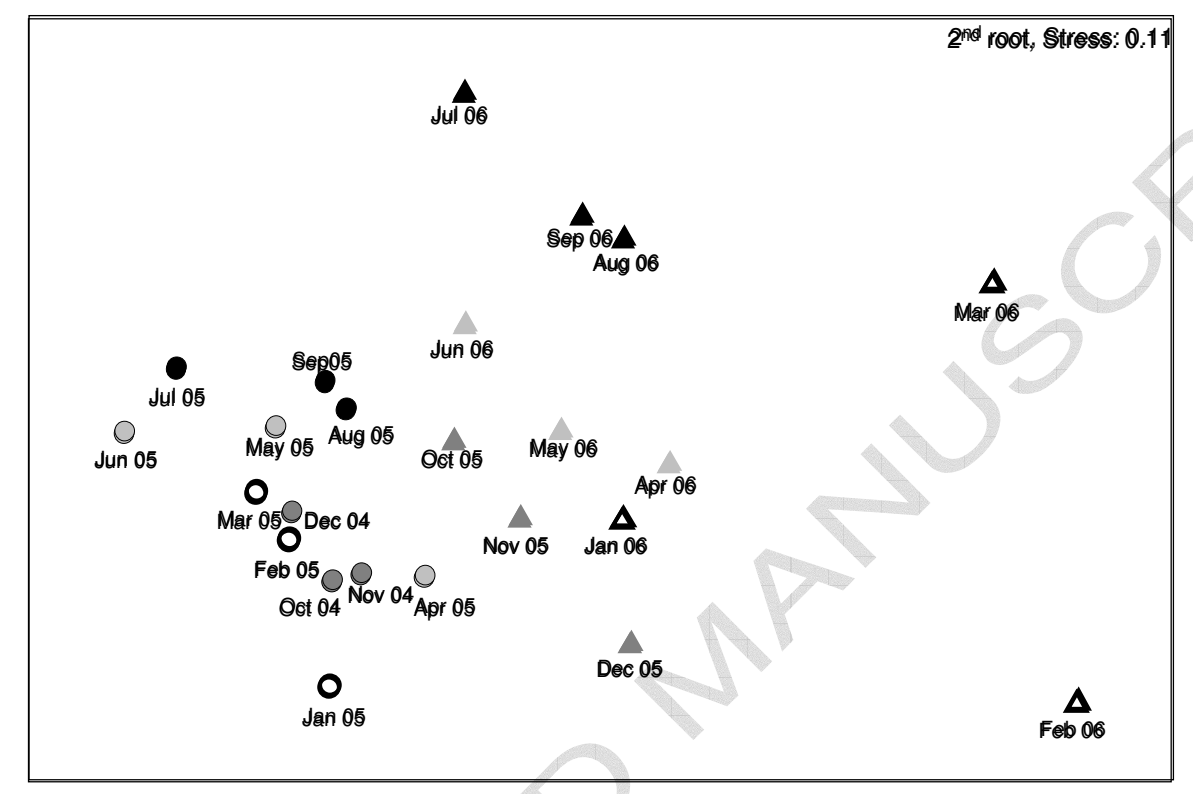

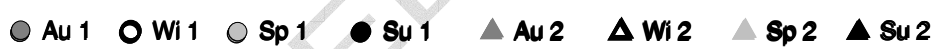

Massamba N'Siala et al., FIGURE 3 


\section{ACCEPTED MANUSCRIPT}
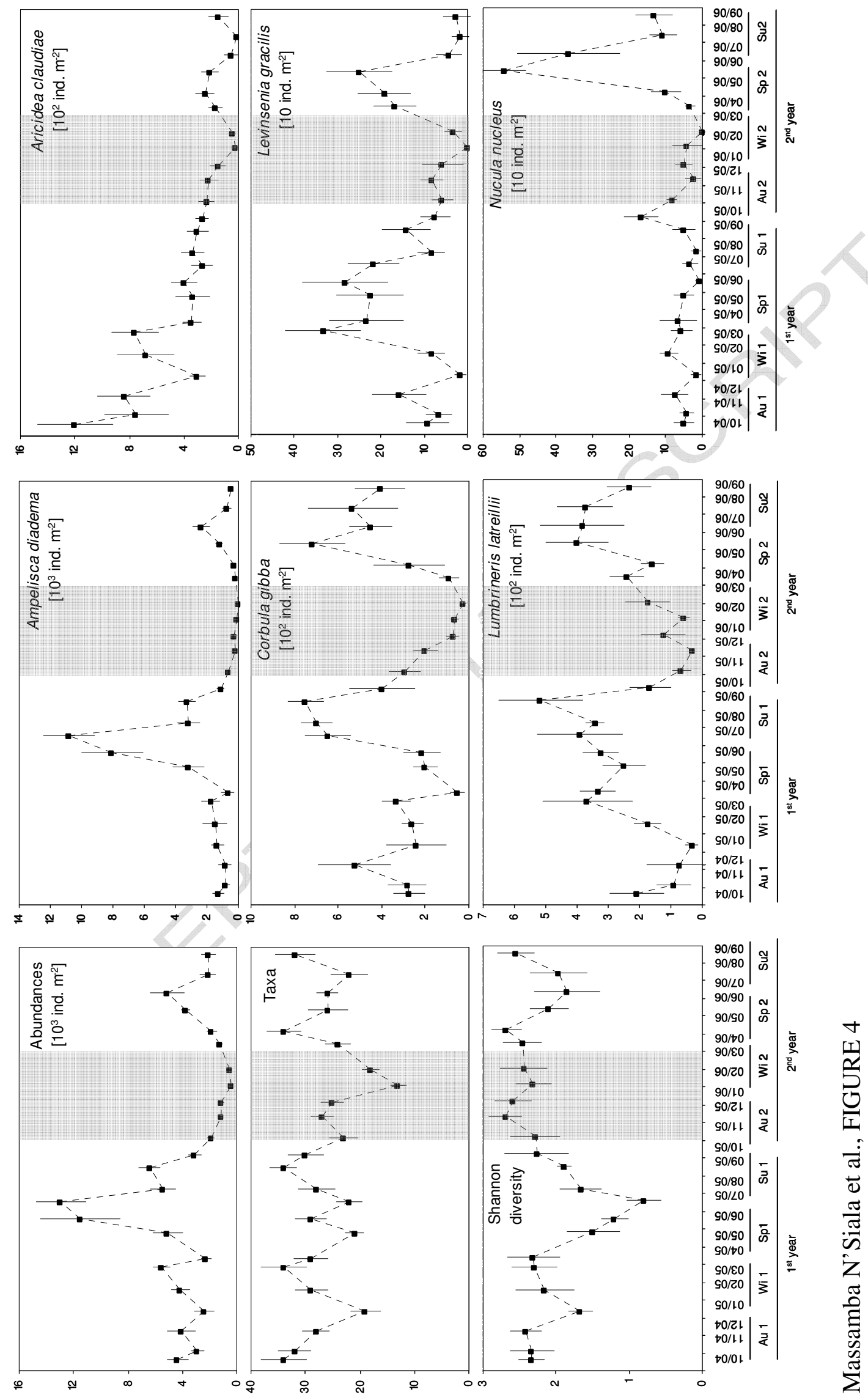

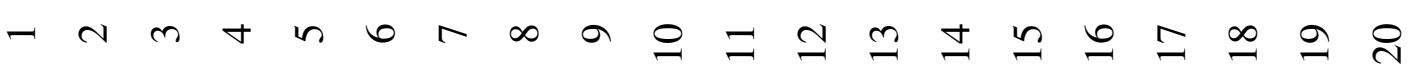

